\title{
Developmental programming: prenatal androgen excess disrupts ovarian steroid receptor balance
}

\author{
Hugo H Ortega, Natalia R Salvetti and Vasantha Padmanabhan ${ }^{1}$ \\ Department of Morphological Sciences, Faculty of Veterinary Sciences, National University of Litoral, Esperanza \\ 3800, Santa Fe, Argentina and Argentine National Research Council (CONICET) and ${ }^{1}$ Department of Pediatrics and \\ the Reproductive Sciences Program, University of Michigan, 300 North Ingalls Building, Room 1109 SW, Ann Arbor, \\ Michigan 48109-0404, USA
}

Correspondence should be addressed to V Padmanabhan; Email: vasantha@umich.edu

\begin{abstract}
Steroid hormones play an important role in reproduction and the receptors through which they signal change in a developmental time, follicle stage, and cell-specific manner. Disruption in steroid receptor expression affects follicle formation and differentiation. In this study, using prenatal testosterone (T) and dihydrotestosterone (DHT)-treated female sheep as model systems, we tested the hypothesis that prenatal androgen excess disrupts the developmental ontogeny of ovarian steroid receptor protein expression. Pregnant Suffolk ewes were injected twice weekly with T propionate or DHT propionate (a non-aromatizable androgen) in cottonseed oil from days 30 to 90 of gestation. Changes in ovarian estrogen receptors (ER; ESR1, ESR2), androgen receptor (AR) and progesterone receptor (PGR) proteins were determined at fetal (days 90 and 140), postpubertal (10 months), and adult (21 months; only prenatal T-treated sheep studied) ages by immunohistochemistry. Prenatal T and DHT treatment induced selective increase in AR but not ER or PGR expression in the stroma and granulosa cells of fetal days 90 and 140 ovaries. An increase in ESR1 and decrease in ESR2 immunostaining coupled with increased AR expression were evident in granulosa cells of antral follicles of 10- and 21-month-old prenatal $\mathrm{T}$ but not DHT-treated females (analyzed only at 10 months). These findings provide evidence that an early increase in ovarian AR is the first step in the altered ovarian developmental trajectory of prenatal T-treated females, and manifestations of postnatal ovarian dysfunction are likely facilitated via altered equilibrium of antral follicular granulosa cell ER/AR protein expression.

Reproduction (2009) 137 865-877
\end{abstract}

\section{Introduction}

Steroids play a key role in the growth, differentiation, and function of female reproductive tissues (Drummond et al. 2002, Yeh et al. 2002, Simpson et al. 2005, Padmanabhan et al. 2006). As such, inappropriate activation of the reproductive system by exposure to excess steroid hormones is a major concern, especially in the female. At risk is the female fetus whose mother has been exposed to exogenous steroids for a variety of reasons: failed contraception and continued exposure to contraceptive steroids, use of anabolic steroids, or inadvertent exposure to environmental compounds with estrogenic or androgenic activity (Bahrke et al. 1998, Crews \& McLachlan 2006, Crain et al. 2008, Jellesen et al. 2008, Woodruff \& Walker 2008). Evidence exists in support of excess native or environmental steroid exposure. For instance, serum testosterone (T) levels in $40 \%$ of female fetuses at mid-gestation were found to be in the male range (Beck-Peccoz et al. 1991). Amniotic fluid T levels were found to be also elevated in diabetic pregnancies (Barbieri et al. 1986). Furthermore, female stillbirth offspring of diabetic mothers have hirsutism, ovarian theca-lutein cysts, and thecal cell hyperplasia (Driscoll et al. 1960), indicative of excess androgen exposure. Evidence exists in support of biologically significant levels of unconjugated bisphenol-A, an environmental estrogen mimic, in maternal and fetal serum (Schonfelder et al. 2002, Padmanabhan et al. 2008). Experimentally, exposure of sheep or monkey fetuses to excess $T$ during gestation culminates in a metabolic and reproductive phenotype (Abbott et al. 2006, Padmanabhan et al. 2006, Dumesic et al. 2007) similar to that of women with polycystic ovary syndrome (PCOS; Dunaif 1997, Rosenfield 1997, Franks et al. 2006), the most common cause of anovulatory infertility in women. Extensive investigations have been undertaken in sheep comparing prenatal $\mathrm{T}$ (signals through androgen receptor (AR) or estrogen receptor (ER), due to aromatization to estrogen), and dihydrotestosterone (DHT; non-aromatizable androgen; signals mainly through AR) to delineate the roles of androgen and estrogen in disrupting neuroendocrine feedback systems (Wood \& Foster 1998, Robinson et al. 2002), and more 
recently ovarian follicular recruitment (Steckler et al. 2005, Smith et al. 2009) and persistence (Manikkam et al. 2006, Steckler et al. 2007). These studies have shown that androgens program the disruptive effects of prenatal $T$ excess on estradiol $\left(E_{2}\right)$ negative but not positive feedback at the neuroendocrine level and follicular recruitment but not persistence at the ovarian level.

Considering that the genomic effects of steroids are mediated via intracellular receptors (Chan \& O'Malley 1976, Tenbaum \& Baniahmad 1997, Beato \& Klug 2002), and steroids have the potential to up- or downregulate their own receptors (Chadha et al. 1994, Tetsuka \& Hillier 1996, Drummond et al. 1999), the disruptive effects of prenatal $T$ excess at the ovarian level may be mediated via altered developmental expression of ovarian steroid receptors. Changes in receptor expression would result in altered steroid signaling culminating in changes in follicle formation and differentiation (Rosenfeld et al. 2001, Drummond et al. 2002, Walters et al. 2008). During fetal ontogeny in sheep, expression of AR, ESR1, ESR2, and progesterone receptor (PGR) undergo progressive follicular type-, cell-, and time-specific changes (Juengel et al. 2006). In this study, using prenatal T- and DHT-treated female sheep as model systems, we tested the hypothesis that prenatal androgen excess disrupts the normal developmental progression of ovarian steroid receptor expression.

\section{Results}

\section{Antibody specificity}

Results from western blot analyses of ovarian and uterine (positive control) homogenate (left) and immunohistochemical recognition of the four steroid receptors in ovarian sections (middle) are summarized in Fig. 1. The negative controls (right) demonstrate the specificity of the antibody. Western blot analysis only found positive bands of appropriate sizes for each of the receptors studied (ESR1, ESR2, AR, and PGR). The ESR1 and ESR2 antibodies detected a single band at 66 and $55 \mathrm{kDa}$ respectively. PGR (isoform B) was detected as a single band at $116 \mathrm{kDa}$ while two bands were observed for AR around $110 \mathrm{kDa}$. In the absence of the primary antibodies, no specific bands were detected (not shown). Specific nuclear staining was detected for all four nuclear receptors studied in the ovaries (Fig. 1). Faint cytoplasmic staining was also evident and this was subtracted as background in the image analysis.

\section{Ovarian ESR1, ESR2, AR, and PGR localization}

In control animals, patterns of AR, ESR1, ESR2, and PGR immunostaining in the various ovarian compartments and follicular classes followed what has been reported earlier (Juengel et al. 2006). Representative patterns of
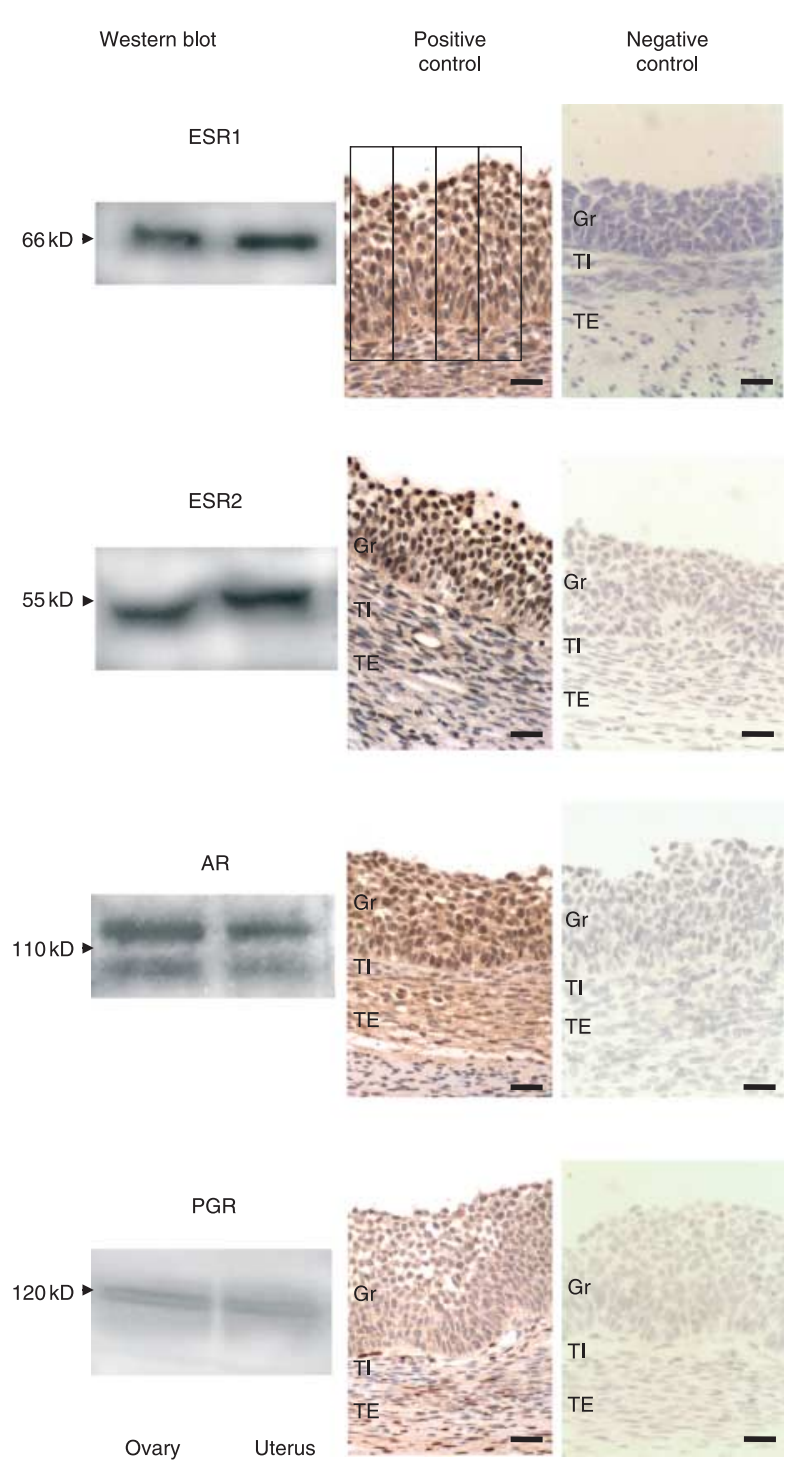

Figure 1 Verification of antibody specificity by western blot analyses of ovarian and uterine homogenate (left) and immunohistochemical recognition of the four steroid receptors in ovarian sections (middle). Negative controls demonstrating the specificity of the antibody are also shown (right). GR, granulosa cells; TI, theca interna; TE, theca externa. Bar $=25 \mu \mathrm{m}$.

AR immunostaining in primordial, primary, and preantral follicles from fetal day-140 ovaries and AR, ESR1, and ESR2 in antral follicles of 10-month old control, and prenatal T-treated females are shown in Fig. 2. In general, changes in steroid receptor expression induced by prenatal steroid treatment were evident only at the level of AR at all three fetal time points studied. In 10- and 22-month-old animals, prenatal steroid-induced changes were evident at the level of AR, ESR1, and ESR2. No changes in PGR were evident at any of the developmental time points studied. Prenatal steroidinduced changes in steroid receptor expression in the various ovarian compartments and follicular classes are discussed below within each developmental time point. 


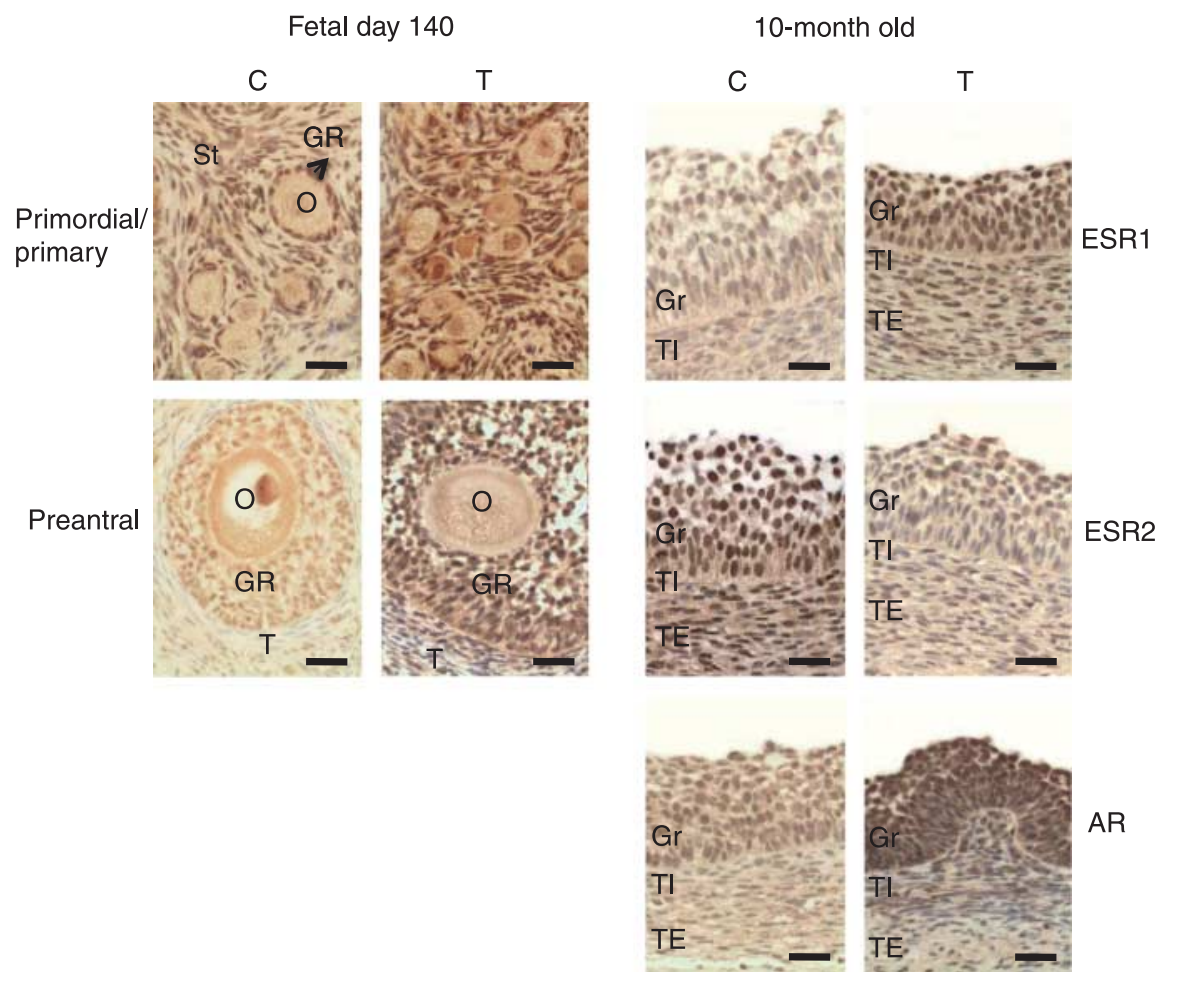

Figure 2 Representative images of $A R$ in primordial/primary and preantral (fetal day 140) and ESR1, ESR2, and AR in antral follicles (10-months old). GR, granulosa cells; $\mathrm{T}$, theca; $\mathrm{TI}$, theca interna; $\mathrm{TE}$, theca externa; Str, stroma; O, oocyte. Bar $=30 \mu \mathrm{m}$.

\section{Fetal}

Relative expression of ESR1, ESR2, AR, and PGR-B proteins in the ovaries of fetal days 90 and 140 are summarized in Fig. 3A. For reference, the previously published distributions of primordial and growing follicles in the contralateral ovary (Smith et al. 2009) are summarized in Fig. 3B. ESR1 and ESR2 proteins were expressed predominantly in granulosa of primordial, primary, and preantral (day 140 only) follicles and stroma at both fetal ages with very little expression in the oocytes. Expression levels of these two receptor proteins in prenatal T- and DHT-treated females in all ovarian compartments did not differ $(P>0.05)$ from those of controls at these two ages. AR protein was expressed in the granulosa, theca, and stromal compartments (Fig. 2). In fetal D90 ovaries, expression was the highest in the stroma $(P<0.05$; Fig. 3A). Comparing across treatments, prenatal $\mathrm{T}$ and DHT excess increased $(P<0.05) \mathrm{AR}$ expression in granulosal, thecal, and stromal compartments (Fig. 3A). PGR-B was expressed in granulosa, theca, and stroma with expression being the highest in theca $(P<0.05)$. Prenatal T and DHT did not alter expression pattern of PGR-B. Only a few antral follicles were present at fetal day 140 and hence were not quantified.

\section{Postpubertal}

Mean changes in expression of the four receptor proteins in the various ovarian compartments of postpubertal females (10 months) are summarized

in Fig. 4A. For reference, the previously published distributions of primordial and growing follicles in the same ovary used in this study (Smith et al. 2009) are summarized in Fig. 4B. As was the case with fetal ovaries, ESR1 and ESR2 immunostaining was predominant in granulosa of primordial, primary, and preantral follicles, with amounts in theca being lower than that in granulosa $(P<0.05)$. Similar direction of changes was observed in the antral follicles with expression being high in granulosa, very low in oocytes, and intermediate in theca interna and externa (Fig. 2). Comparing across treatments, effects of prenatal $\mathrm{T}$ and $\mathrm{DHT}$ excess were unidirectional with both increasing ESR1 expression in granulosa of large preantral and antral follicles as well as in the stromal compartment $(P<0.05$; representative patterns in control and prenatal T-treated females in Fig. 2, right). ESR2 expression followed a completely different trajectory and was manifested in a tissueand steroid-specific manner. Prenatal steroid excess induced changes in ESR2 expression only in antral follicles and the stromal compartment $(P<0.05$; representative patterns in control and prenatal T-treated females in Fig. 2, right). Prenatal $\mathrm{T}$ but not DHT excess reduced ESR2 expression in both granulosa and theca interna $(P<0.05)$. By contrast, prenatal $\mathrm{T}$ and $\mathrm{DHT}$ excess increased ESR2 expression in the stroma $(P<0.05)$. In theca externa, both treatments reduced the level of ESR2 immunostaining $(P<0.05)$. 
A
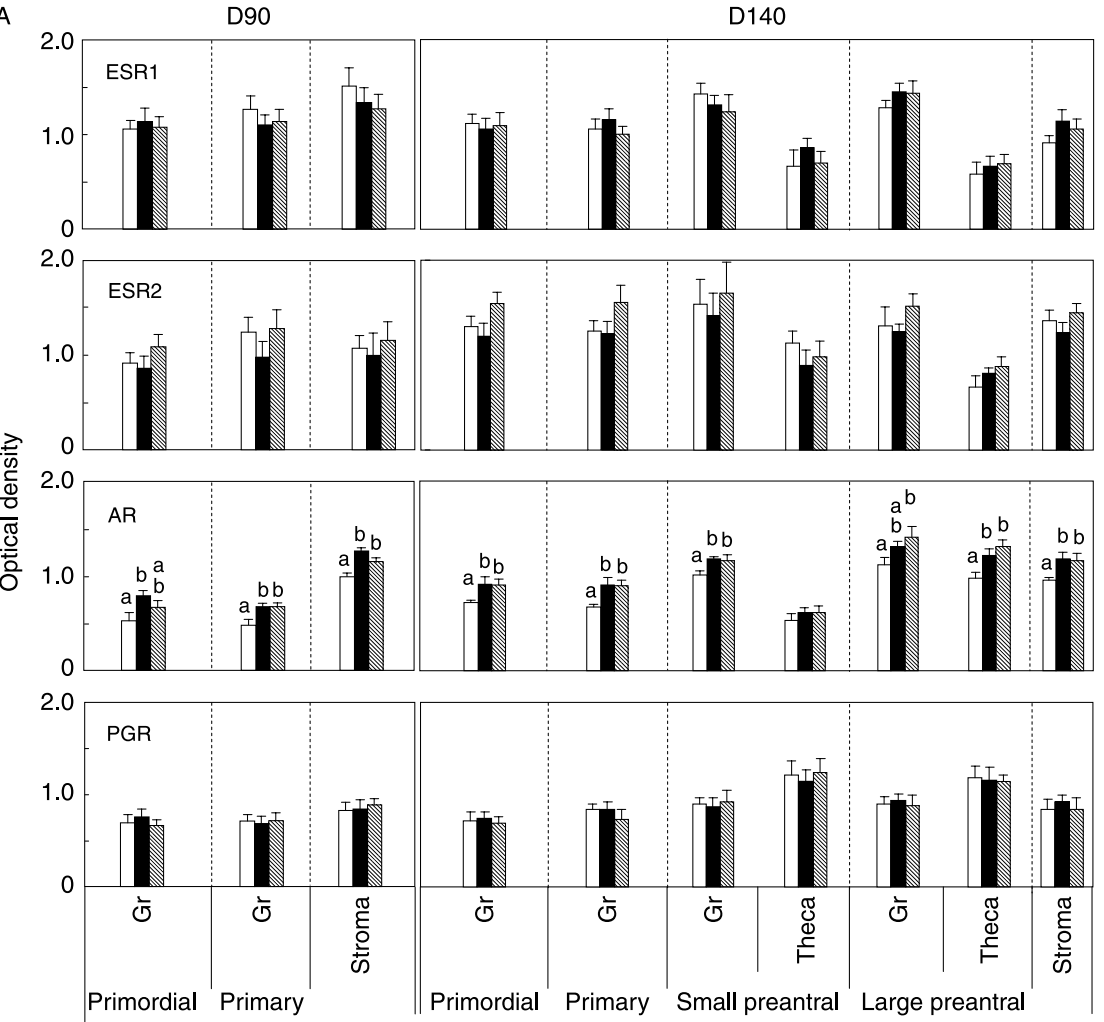

B

\begin{tabular}{lccc}
\hline & Control & Prenatal T & Prenatal DHT \\
\hline Fetal day 90 & & & \\
Primordial follicles & $49433 \pm 8683$ & $54447 \pm 6609$ & $62602 \pm 9506$ \\
Growing follicles & $1732 \pm 640$ & $2297 \pm 1613$ & $738 \pm 543$ \\
Fetal day 140 & & & \\
Primordial follicles & $88629 \pm 11832$ & $86219 \pm 11375$ & $64239 \pm 12622$ \\
Growing follicles & $1638 \pm 337$ & $4071 \pm 802^{*}$ & $3547 \pm 862^{*}$ \\
\hline
\end{tabular}

Figure 3 (A) Relative expression (measured as optical density) of ESR1, ESR2, AR, and PGR-B in ovaries of control (open bars), prenatal T-treated (black bars), and prenatal DHT-treated (hatched bars) day-90 and day-140 fetuses. For each cellular compartment within each follicle type, values with different letters are significantly different $(P<0.05)$. Expressions of these receptors were low in oocytes and did not differ between treatment and follicular classes (not shown). Values represent mean \pm s.E.M. Day 90 (six C fetuses from six dams, six T-treated fetuses from six dams, and six DHT-treated fetuses from five dams). Day 140 (six control fetuses from five dams, seven T-treated from seven dams, and five DHT-treated from five dams). (B) Published summary of ovarian stereology results (Smith et al. 2009) from the contralateral ovary documenting enhanced follicular recruitment in prenatal T- and DHT-treated day- 140 but not day-90 fetuses for comparison. Asterisks indicate significant differences from controls.
AR immunostaining followed a similar trend as in the fetuses with higher amounts found in granulosa and stroma $(P<0.05)$. In contrast to the fetal ovaries, prenatal $\mathrm{T}$ and DHT excess had no effect on $A R$ protein expression in granulosa of primordial, primary, and small prenatal follicles. However, prenatal T excess increased granulosal expression of AR protein in large preantral and antral follicles while reducing expression in stromal cells $(P<0.05)$. Effects of prenatal DHT excess parallel that of prenatal $T$ at the stromal level with both reducing $A R$ immunostaining $(P<0.05)$. Changes in PGR-B for the most part were similar to that of fetal ovaries. Predominant PGR-B protein expression at this age was evident in thecal and stromal cells, with almost twice the amount as seen in granulosa cells $(P<0.05)$. Prenatal $\mathrm{T}$ and DHT treatment had no effect on PGR-B immunostaining in any ovarian compartment at this age $(P>0.05)$.

\section{Adult}

Changes in expression pattern of the four receptor proteins in the ovarian compartments of adult females are shown in Fig. 5. Note that the comparison is only between control and prenatal $\mathrm{T}$ as insufficient prenatal DHT females were born for including an adult group. Expression of ESR1 protein in follicular classes at this age paralleled that of fetal and 10-month-old animals. Prenatal $T$ excess increased ESR1 immunostaining in granulosa and stroma $(P<0.05)$ as was the case with 10 -month-old animals. Expression pattern of ESR2 protein also paralleled that of 10-month-old animals with prenatal $T$ excess reducing expressions in granulosa and theca of antral follicles but increasing expression in stroma $(P<0.05)$. Both $A R$ and PGR-B immunostaining also followed similar changes as in the 10-month-old females. While no effect of prenatal $T$ excess was 
A
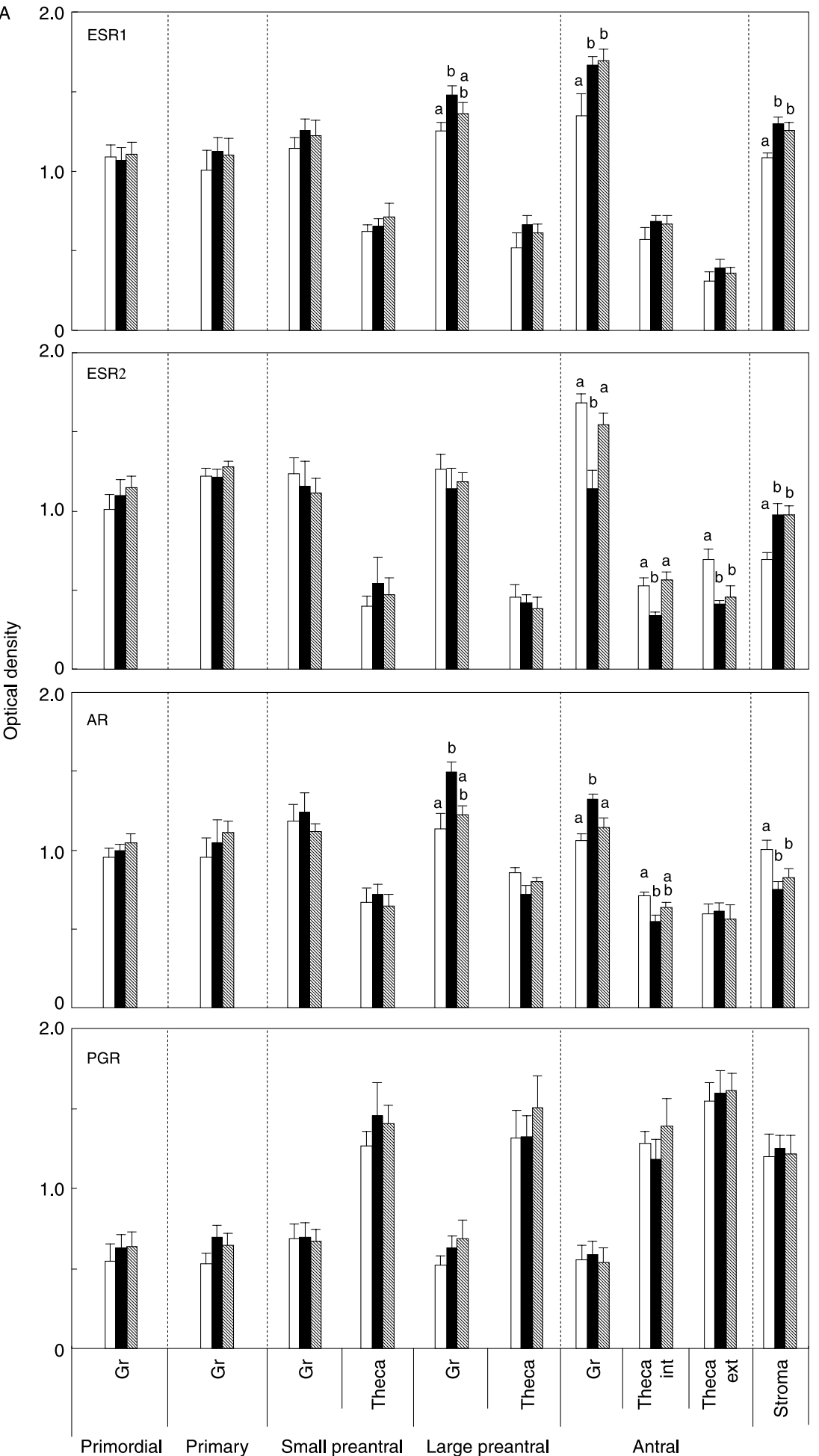

B

\begin{tabular}{lccc}
\hline & Control & Prenatal T & Prenatal DHT \\
\hline Primordial follicles & $58731 \pm 9602$ & $24250 \pm 3364^{\star}$ & $38298 \pm 10192$ \\
Growing follicles & $158 \pm 35$ & $240 \pm 15^{\star}$ & $139 \pm 28$ \\
\hline
\end{tabular}

Figure 4 (A) Relative expressions of ESR1, ESR2, $A R$, and PGR-B in the ovaries of 10-month-old control (open bars), prenatal T-treated (black bars) and prenatal DHT-treated (hatched bars) females. For each cellular compartment within each follicle type, values with different letters are significantly different $(P<0.05)$. Values represent mean \pm S.E.M. of five control animals from five dams, six T-treated animals from six dams, and five DHT-treated animals from five dams. (B) Published summary of ovarian stereology results (Smith et al. 2009) from the same ovary used in this study, which document enhanced follicular depletion and recruitment in prenatal T- but not DHT-treated 10-monthold females for comparison. Asterisks indicate significant differences from controls. 

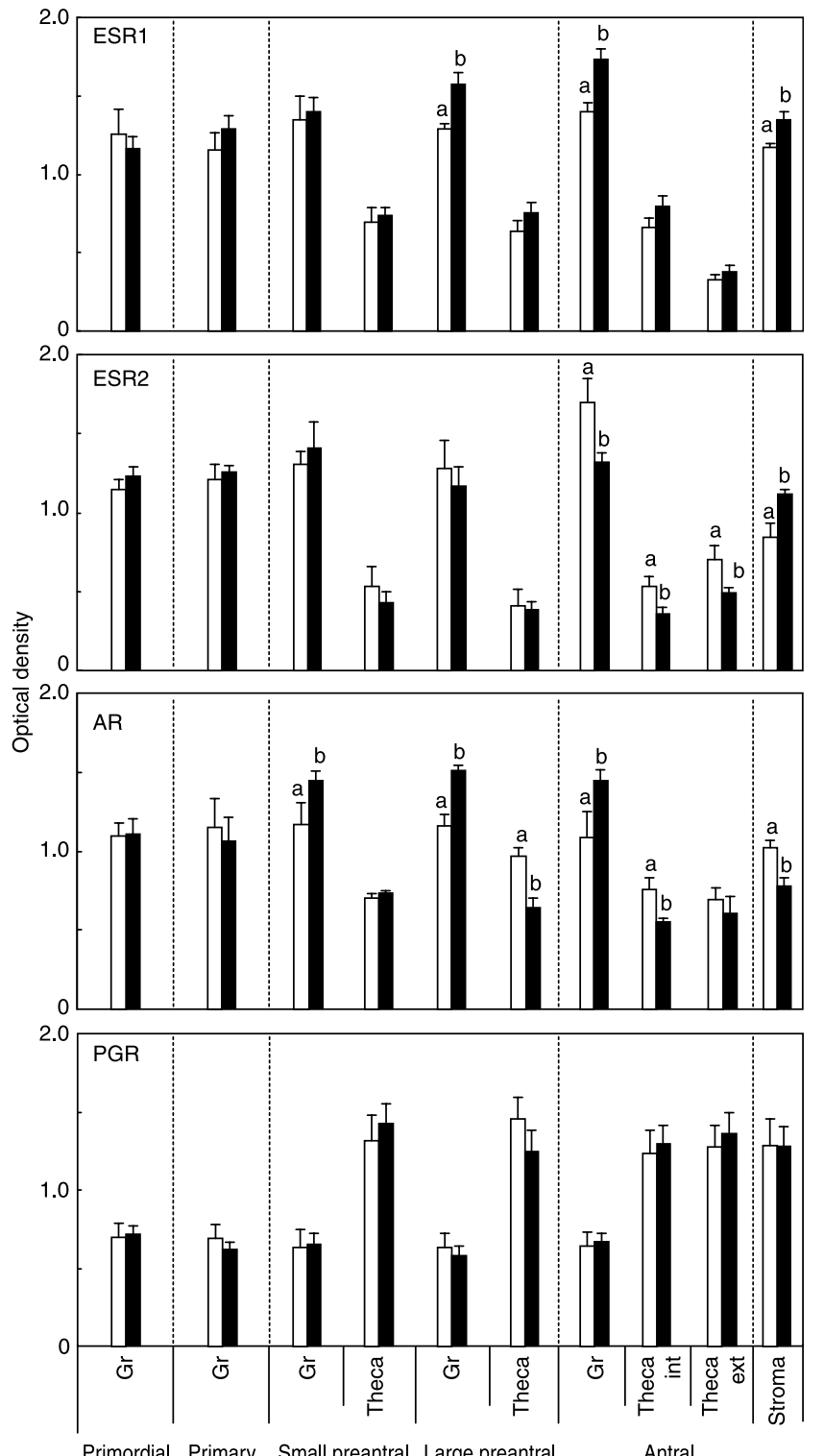

Figure 5 Relative expressions of ESR1, ESR2, AR, and PGR-B in the ovaries of 21-month-old control (open bars) and prenatal T-treated (black bars) females. For each cellular compartment within each follicle type, values with different letters are significantly different $(P<0.05)$. Values represent mean \pm s.E.M. of five control animals from five dams, eight prenatal T-treated animals from eight dams. Note that stereology has not been undertaken with 21 -month-old animals.

seen in PGR-B, AR immunostaining was increased in granulosa cells of preantral and antral follicles but reduced in theca and stroma $(P<0.05)$.

\section{Discussion}

Findings from this study provide evidence that prenatal Tand DHT excess alters the ontogeny of ESR1, ESR2, and AR but not PGR-B protein expression in the ovary, in a developmental time, steroid, and follicular stage and cell-specific manner. Furthermore, the finding that the changes are manifested during fetal life exclusively at the level of AR but not ER/PGR indicates that resulting adult ovarian perturbations that the prenatal T-treated females manifest, namely disrupted ovarian morphology, follicular persistence, and depletion (Manikkam et al. 2006, Steckler et al. 2007, Smith et al. 2009), are reprogrammed via altered AR signaling. The significance of the changes in steroid receptor proteins observed during the different developmental time points is discussed below.

\section{Fetal}

The selective increase in AR but not ER or PGR-B immunostaining in the stroma and granulosa of primordial and primary follicles of fetal day-90 ovary at the end of T treatment suggests that this is a key step in programming adult dysfunction. Administration of $\mathrm{T}$ propionate to prepubertal rats on day 5 of postnatal life also increased ovarian nuclear AR expression (Bukovsky et al. 2002). Developmentally, complete follicular differentiation (primordial to antral) is completed postnatally in rodents as opposed to sheep, in which it is completed in utero (Padmanabhan et al. 2007). The increased AR expression in fetal day-90 ovaries of prenatal T-treated sheep appears to be mediated by androgenic actions of $\mathrm{T}$ because the non-aromatizable androgen, DHT, also increased AR immunostaining in stromal as well as granulosa of primordial/primary follicles of day-90 fetuses.

Increase in AR immunostaining in stromal and granulosa compartments of fetal day-140 ovaries, coupled with enhanced follicular recruitment seen at this developmental time point in these very same animals (Smith et al. 2009), is consistent with androgens playing a role in early follicular differentiation (Hillier \& Tetsuka 1997, Vendola et al. 1998, Walters et al. 2008). Androgens have been shown to recruit primordial follicles into the growing pool of developing follicles (Hillier \& Tetsuka 1997, Vendola et al. 1998, McGee \& Hsueh 2000). Recent studies using a well-characterized culture system have found that $\mathrm{T}$ stimulates primary to secondary follicle transition via an AR-dependent mechanism (Yang \& Fortune 2006). Earlier findings that the AR knockout mice show accelerated follicle depletion at older ages (Shiina et al. 2006) and the testicular-feminized mice, which express a truncated non-functional $A R$, have a shortened reproductive lifespan (Young et al. 1989, Gaspar et al. 1991) indicate that AR might play a physiological role in determining the reproductive lifespan of the ovary. These findings are at odds with enhanced follicular depletion of the 10-month-old prenatal T-treated sheep manifest (Smith et al. 2009) in the face of increased AR during fetal life (this study). One possibility is that there is a threshold requirement of $A R$ for the occurrence of normal ovarian 
differentiation, amounts of AR above or below which would be detrimental to follicular survival.

\section{Postpubertal and adult}

Patterns of ESR1, ESR2, and AR immunostaining in ovarian compartments of adult controls were consistent for the most part with what has been described for sheep (Juengel et al. 2006). The altered equilibrium of ESR1 to ESR2 protein coupled with increased AR expression evident mainly in antral follicles of 10 - and 21 -month-old prenatal T-treated females might be a contributing factor in the development of follicular persistence that the prenatal T-treated females have been found to manifest in our earlier studies (Manikkam et al. 2006, Steckler et al. 2007). Antral follicles represent a stage in follicular development, at which maximal proliferation is occurring. Rodent studies have found that $E_{2}$ synergizes with $\mathrm{FSH}$ in stimulating granulosal cell proliferation and steroidogenesis (Palter et al. 2001, Drummond 2006). The similarity in the direction of changes in ESR1 to ESR2 immunostaining in ovaries of 10- and 21-month-old animals is supportive of inherent reprogramming of the ovary.

Interestingly, ESR1 overexpressed mice are subfertile and show down-regulation of the Esr2 gene (Tomic et al. 2007). This observation raises the possibility that the decrease in ESR2 seen in granulosa of antral follicles of prenatal T-treated females may be secondary to ESR1 up-regulation. The increased numbers of antral follicles observed in ESR1 overexpressed mice (Tomic et al. 2007) parallel the increased number of antral follicles seen in the 10-month-old prenatal T-treated female sheep (same animals used in this study; Smith et al. 2009). These findings are consistent with a role for estrogen in promoting follicular growth via ESR1 receptor. Studies with ESR1 knockout mice that were anovulatory also indicated that ESR1 is not required for follicular recruitment or early differentiation but necessary for subsequent follicular growth (Dupont et al. 2000).

Another possibility to consider is that it is not the increased ESR1 but the relative expression of ESR1 to ESR2 that is more important, because the 10-month-old prenatal DHT-treated females, which failed to show the decrease in ESR2 (this study), did not show increased presence of antral follicles (Smith et al. 2009). Because ESR1 and ESR2 can form homodimers as well as heterodimers (Pettersson et al. 1997) and both ESR1 and ESR2 are expressed in the granulosa, theoretically they should be capable of forming ESR1:ESR1 and ESR2:ESR2 homodimers as well as ESR1:ESR2 heterodimers and alter signal transduction. ESR1 and ESR2 homodimers and heterodimers can have different affinities/specificities for estrogen or other potential estrogen-like ligands (Sun et al. 1999) and cause differential gene activation (Mclnerney et al. 1998,
Pettersson et al. 2000). Earlier studies have found that ESR2, when present within a heterodimer, repressed ESR1 activity and sensitivity to $E_{2}$ (Hall \& McDonnell 1999). More recent studies have suggested that the main determinants of the transcriptional activities of ESR1 and ESR2 are not their binding ability but rather the individual concentration of the two receptors in target cells and the structure of the estrogen ligand (Gougelet et al. 2007, Bhavnani et al. 2008). As such, a given ligand could exert opposite activities depending on the type of ER expressed. Therefore, regulation of ovarian differentiation and subsequent function in adulthood by estrogen appears to be complex and involve intricate interactions/cell signaling pathways coordinated by different receptor-receptor interactions (Pettersson et al. 1997, Mclnerney et al. 1998, Hall \& McDonnell 1999, Sun et al. 1999, Pettersson et al. 2000, Gougelet et al. 2007, Bhavnani et al. 2008). If so, induction of changes in the ESR1:ESR2 ratio such as that seen in prenatal T-treated females would perturb the effects of estrogen in regulating ovarian function.

The disruptive effects of altered ER signaling may be compounded further by altered AR signaling in antral follicles of 10- and 21-month-old females. Findings from this study coupled with earlier findings of multifollicular ovaries, reduced inhibin/activin $\beta B$ mRNA expression (West et al. 2001), enhanced follicular recruitment (Steckler et al. 2005, Smith et al. 2009 (same animals as used in this study)), and follicular persistence (Manikkam et al. 2006, Steckler et al. 2007), in prenatal T-treated sheep all point to disrupted intra-follicular androgen signaling. It is known that androgens promote atresia and/or arrest of follicles (Hillier \& Tetsuka 1997, Vendola et al. 1998, McGee \& Hsueh 2000). Furthermore, $T$ antagonizes the anti-apoptotic effects of $E_{2}$ in rat granulosal cells in early antral and preantral follicles (Billig et al. 1993). Our earlier findings of follicular persistence in prenatal T- but not DHT-treated females (Manikkam et al. 2006, Steckler et al. 2007) are therefore consistent with increased AR protein in granulosa cells of antral follicles of prenatal T- but not DHT-treated females. The fact that the direction of changes in AR expression was tissue/follicle stage specific and a function of the nature of prenatal steroid exposure emphasizes the specificity of this regulation and the importance of these findings to ovarian function.

The finding that AR expression was increased only in granulosa cells of antral follicles from adult animals is also consistent with reduced ESR2 expression seen in prenatal T-treated females. Earlier studies have found that AR expression in the granulosa of late antral follicles is repressed by the activation of ESR2 (Cheng et al. 2002). Repression of AR changes the follicular environment from androgen to estrogen dominance, a critical step for the survival of the follicle (Billig et al. 1993, Hillier \& Tetsuka 1997, Britt \& Findlay 2002, Drummond 2006, Yang \& Fortune 2006). If AR expression remains high, 
as is the case in prenatal T-treated females, antral follicles cannot achieve estrogen dominance and their fate is atresia or arrest. However, parallel studies performed using the same ovaries as used in this study (Smith et al. 2009) found no differences in the percentage of atretic antral follicles between control and prenatal T-treated females at 10 months of age. On the contrary, our earlier findings of follicular persistence in the prenatal T-treated females (Manikkam et al. 2006, Steckler et al. 2007) provide evidence in support of arrested follicular development. It remains to be determined whether this arrest is mediated via a shift in the balance of apoptotic to anti-apoptotic factors in these follicles. It is of interest that granulosa cells of antral follicles derived after gonadotropin stimulation from women with PCOS, whose reproductive attributes the prenatal T-females duplicate, also exhibit increased AR expression compared with controls (Catteau-Jonard et al. 2008) and flutamide, an anti-androgen, restores ovulatory function in anovulatory women with PCOS (De Leo et al. 1998).

While changes in ER and AR likely play a role in the manifestation of ovarian disruptions in the adult prenatal T-treated females, the lack of changes in PGR-B indicate that this isoform of PGR is not involved. However, the finding that double PGR (PGR-A and PGR-B) knockout mice fail to ovulate (Lydon et al. 1995) provides evidence that other PGR isoforms may be involved. Consistent with this premise, cystic ovaries of rats manifested higher expression of PGR-A, lower expression of the PGR-C, and no change in PGR-B isoform (Salvetti et al. 2009). Changes in the expressions of other PGR forms were not evaluated in this study.

The fetal ovarian changes in AR and changes in $A R / E R$ at 10 months of age are consistent with the effects of prenatal T and DHT treatments on follicular recruitment, depletion, and ovarian morphology reported in these very same animals (Smith et al. 2009). The increased fetal ovarian AR expression (this study) coupled with the increased follicular recruitment (Smith et al. 2009) in fetal day-140 prenatal T- and DHT-treated fetuses supports a role for androgen in early follicular activation. Similarly, increased follicular depletion and ovarian disruptions seen in the 10-monthold prenatal T-treated but not DHT-treated females (same animals used in this study; Smith et al. 2009) coupled with selective changes in the expression of ESR2 in antral follicles of 10-month-old prenatal T- but not DHT-treated females (this study) are also consistent with a role for estrogen. In distinguishing between androgenic versus estrogenic contribution, similarity of responses between prenatal $\mathrm{T}$ (aromatizable androgen) and prenatal DHT-treated (non-aromatizable androgen) females was used as an index to imply androgenic action. While evidence exists that DHT can be metabolized into $5 \alpha$-androstane-3 $\beta, 17 \beta$-diol ( $3 \beta$-diol) and has the ability to act via the ESR2 receptor (Handa et al. 2008), there is very little information available regarding the extent and impact of this conversion at the ovarian level. Nonetheless, selective changes in AR and ER expressions seen in this study help to distinguish which receptor signaling are involved and the developmental time point when this occurs.

Finally, it is unclear how the fetal changes in AR induced by prenatal $T$ excess reprogram the ovary to culminate in adult ovarian dysfunction. A likely possibility involves epigenetic modifications of key ovarian regulatory genes. Earlier studies have found that sex steroids have the ability to influence the methylation state of DNA sequences and both ER and AR acetylation can be regulated by physiologic stimuli (Leader et al. 2006a, 2006b, Vottero et al. 2006, Xue et al. 2007). The findings from this study are consistent with the recent proposal of a two-step process (Tang et al. 2008) whereby early insult from in utero $T$ treatment resets the course of ovarian development and the manifestation of adult ovarian phenotype requires subsequent exposure to ovarian steroids such as that occurring during puberty (Tang et al. 2008).

In summary, this comprehensive reproductive lifespan study relates the impact of prenatal exposure to excess sex steroids on the developmental trajectory of ovarian steroid receptors. The findings provide evidence that the first step in the altered trajectory of ovarian differentiation of prenatal T-treated females involves an early increase in ovarian AR and that manifestation of postnatal ovarian dysfunction is likely mediated via an increase in the ratio of ESR1/ESR2 receptor coupled with an increase in granulosal expression of AR resulting in increased AR signaling and consequent follicular persistence. The findings may be of translational significance to women with polycystic ovarian disease, the reproductive and metabolic phenotypes of whom the prenatal T-treated females manifest.

\section{Materials and Methods}

\section{Breeding and prenatal treatment}

All procedures used in this study were approved by the Institutional Animal Care and Use Committee of the University of Michigan and were consistent with the National Research Council's Guide for the Care and Use of Laboratory Animals. Two to three-year-old Suffolk ewes were purchased locally and bred in a farm receiving oversight from University of Michigan, Department of Laboratory Animal Medicine. Day of mating was determined by visual confirmation of a paint mark left by an intact ram on the hindquarter of bred ewes. Beginning on day 30 of gestation and continuing until day 90 of gestation, pregnant ewes were injected i.m. twice weekly with $100 \mathrm{mg}$ of T propionate (1.2 mg/kg; Sigma-Aldrich Corp.) or $100 \mathrm{mg}$ DHT propionate (Steraloids, Inc., Newport, RI, USA) suspended in cottonseed oil (Sigma-Aldrich Corp). The dose and mode of treatment were chosen based on the large body of data available documenting postnatal reproductive disruptions 
(Wood \& Foster 1998, Robinson et al. 2002, Manikkam et al. 2004, Steckler et al. 2007). Prenatal T treatment produces circulating concentrations of $\mathrm{T}$ in pregnant sheep and female fetuses in the range seen in intact adult males and male fetuses respectively (Wood et al. 1991). Details of prenatal treatments, husbandry, and nutrition of maternal sheep as well as newborn and growing lambs until 4 months of age have been published previously (Manikkam et al. 2004).

Ovaries procured from control, prenatal T, and DHT-treated females on fetal day 90 (six control fetuses from six dams, six T-treated fetuses from six dams, and six DHT-treated fetuses from five dams), fetal day 140 (six control fetuses from five dams, seven T-treated from seven dams, and five DHT-treated from five dams), 10 months of age (five control animals from five dams, six T-treated animals from six dams, and five DHT-treated animals from five dams), and 21 months of age (five control animals from five dams, and eight T-treated animals from eight dams) were utilized in this study. There were insufficient DHT-treated females born to include a 21-month-old prenatal DHT-treated group.

For collection of ovaries from fetuses, dams were killed by administration of a barbiturate overdose (Fatal Plus, Vortech Pharmaceuticals, Dearborn, MI, USA) and fetuses removed. Biweekly progesterone monitoring found that all controls were cycling at both 10- and 21-month age. Barring one prenatal T-treated female, all prenatal T- and DHT-treated females were cycling at 10 months of age although the Tanimals manifested cycle irregularities. At 21 months of age, three prenatal T-treated animals were anovulatory and the other five showed irregular cycles. To avoid influence of cycle stage in cycling animals, two $20 \mathrm{mg}$ injections of prostaglandin $\mathrm{F}_{2 \alpha}\left(\mathrm{PGF}_{2 \alpha}\right.$, $5 \mathrm{mg} / \mathrm{ml}$ Lutalyse; Pfizer Animal Health, New York, NY, USA) were administered 11 days apart to induce luteolysis and synchronize estrus in cycling females. Ewes were killed $28 \mathrm{~h}$ after second $\mathrm{PGF}_{2 \alpha}$ injection and ovaries collected. There were no differences in dam weights among treatment groups at the time of fetal collection or between control and experimental females at the time of study (data not shown). For immunohistochemical determination of steroid receptors, one ovary from each fetus was fixed in $4 \%$ paraformaldehyde in
PBS ( $\mathrm{pH}$ 7.4), embedded in paraffin, and the entire ovary serially sectioned at $5 \mu \mathrm{m}$ thickness. The second ovary from fetal ages was embedded in plastic stereology (Smith et al. 2009). For adult ovaries, one ovary was fixed in $4 \%$ paraformaldehyde in PBS ( $\mathrm{pH} 7.4)$, embedded in paraffin, and the entire ovary serially sectioned and sections used for morphometry in a parallel study (Smith et al. 2009) and steroid receptor quantification (this study). The other ovary was stored frozen for future in situ hybridization studies.

\section{Western blotting}

Details of antibodies used are summarized in Table 1. To test specificity of the antibodies, sheep ovarian tissues were homogenized in a radio-immunoprecipitation assay lysis buffer consisting of 1\% v/v IGEPAL CA630 (octylphenyl-polyethylene glycol), $0.5 \%(\mathrm{w} / \mathrm{v})$ sodium desoxycholate, $0.1 \% \mathrm{w} / \mathrm{v}$ SDS, $1 \mathrm{mM}$ EDTA, $50 \mathrm{mM}$ sodium fluoride (all from Sigma-Aldrich Corp.), 0.1 M PBS, and a protease inhibitor cocktail (Complete Mini Protease Inhibitor Cocktail Tablets, Roche). Ovarian homogenates were centrifuged at $12000 \mathrm{~g}$ for $20 \mathrm{~min}$ and supernatant stored frozen at $-80{ }^{\circ} \mathrm{C}$. Forty micrograms of protein were separated by SDS-PAGE (10\% resolving gel). Proteins were transferred to nitrocellulose membranes (Amersham), blocked for $1 \mathrm{~h}$ in $2 \% \mathrm{w} / \mathrm{v}$ non-fat milk in Trisbuffered saline containing $0.05 \%$ v/v Tween 20 (Sigma-Aldrich Corp.), and then incubated overnight at $4{ }^{\circ} \mathrm{C}$ with specific primary antibodies (Table 1 ). Following washing, membranes were treated for $1 \mathrm{~h}$ with corresponding secondary peroxidaseconjugated antibody (Table 1). Immunopositive bands were visualized with a chemiluminescent detection kit (ECL, Amersham).

\section{Immunohistochemistry}

A streptavidin-biotin immunoperoxidase method as described previously (Salvetti et al. 2007) was used for immunohistochemical detection. After deparaffinizing and antigen retrieval in $10 \mathrm{mM}$ sodium citrate solution $(\mathrm{pH}$ 6.0) by boiling in

Table 1 Antibodies used for immunohistochemistry (IH) and western blot (WB).

\begin{tabular}{|c|c|c|c|c|}
\hline Antigen & Clone and source & Dilution & IH antigen retrieval & Secondary antibody and dilution \\
\hline ESR1 & $\begin{array}{l}33 \text { (MA1-310, Affinity } \\
\text { Bioreagents, Golden, CO, USA) }\end{array}$ & $\begin{array}{l}\text { IH: } 1: 50 \\
\text { WB: } 1: 200\end{array}$ & Pressure cooker & $\begin{array}{l}\text { IH: biotinylated goat-anti-mouse IgG } \\
\quad(\text { Zymed, San Francisco, CA, USA), 1:100 } \\
\text { WB: goat-anti-mouse IgG peroxidase } \\
\quad \text { (Amersham), 1:500 }\end{array}$ \\
\hline ESR2 & $\begin{array}{l}\text { Polyclonal (PA1-311, Affinity } \\
\text { Bioreagents) }\end{array}$ & $\begin{array}{l}\text { IH: } 1: 50 \\
\text { WB: } 1: 200\end{array}$ & Microwave & $\begin{array}{l}\text { IH: biotinylated goat -anti-rabbit IgG } \\
\text { (Zymed), 1:100 } \\
\text { WB: goat-anti-rabbit IgG peroxidase } \\
\text { (Amersham), 1:500 }\end{array}$ \\
\hline AR & $\begin{array}{l}\text { Polyclonal (PA1-110, Affinity } \\
\text { Bioreagents) }\end{array}$ & $\begin{array}{l}\text { IH: } 1: 200 \\
\text { WB: } 1: 300\end{array}$ & Microwave & $\begin{array}{l}\text { IH: biotinylated goat-anti-rabbit IgG } \\
\text { (Zymed), 1:100 } \\
\text { WB: goat-anti-rabbit IgG peroxidase } \\
\quad \text { (Amersham), 1:500 }\end{array}$ \\
\hline PGR-B ${ }^{a}$ & $\begin{array}{l}\text { Alpha PR6 (MA1-411, Affinity } \\
\text { Bioreagents) }\end{array}$ & $\begin{array}{l}\text { IH: } 1: 50 \\
\text { WB: } 1: 20\end{array}$ & Pressure cooker & $\begin{array}{l}\text { IH: biotinylated goat -anti-mouse IgG } \\
\text { (Zymed), 1:100 } \\
\text { WB: goat-anti-mouse IgG peroxidase } \\
\quad \text { (Amersham), 1:500 }\end{array}$ \\
\hline
\end{tabular}

\footnotetext{
${ }^{\mathrm{a} P G R}$ isoform B.
} 
pressure cooker (ESR1 and PGR) or microwaving (AR and ESR2; Table 1), endogenous peroxidase activity in ovarian sections was quenched with $1 \%(\mathrm{v} / \mathrm{v}) \mathrm{H}_{2} \mathrm{O}_{2}$ in methanol. To eliminate nonspecific binding, sections were incubated with $10 \%(\mathrm{v} / \mathrm{v})$ normal goat serum for $20 \mathrm{~min}$ at room temperature before incubating with the primary antibodies for $18 \mathrm{~h}$ at $4{ }^{\circ} \mathrm{C}$ and then with respective biotinylated secondary antibody for $30 \mathrm{~min}$ at room temperature. The visualization of antigens was achieved with streptavidin-peroxidase (BioGenex, San Ramon, CA, USA) using 3,3-diaminobenzidine (DAB; Dako, Carpinteria, CA, USA) as chromogen. Ovarian sections were counterstained with Mayer's hematoxylin, dehydrated, and mounted. Quenching of residual endogenous peroxidase activity was confirmed by incubating some sections with DAB alone. The specificity of the secondary antibodies was tested with negative control sections processed as above except for replacement of primary antibodies with non-immune serum. As multiple series of histological processing were involved, serial sections of a non-experimental set of sheep ovaries were included with each series to allow normalization across series. Each immunohistochemical series included randomly selected slides with ovarian sections from different ages and treatments. Follicle classes were distinguished using the following criteria: primordial, single layer of flattened granulosa cells; primary, partial or one complete layer of cuboidal granulosa cells; small preantral, more than one to five layers granulosa cells; large preantral, more than five layers of cuboidal granulosa cells, and antral, those with an antral cavity.

\section{Image analysis}

Two sections, the first one-third into the ovary and the second two-thirds into the ovary, were used for immunohistochemical quantification. Considering the follicular sizes (McNatty et al. 1999) and the distance between the two sections ( $\sim 200 \mu \mathrm{m}$ in fetal and $>10 \mathrm{~mm}$ in adult), there is little likelihood of follicular overlap. All growing follicles in both sections were analyzed (ranged between 8 and 15 in follicular classes). For primordial follicles, the slides were scanned left to right from the top and the first 20 primordial follicles that were distinct and showed no overlap with neighboring follicles were utilized. Only healthy follicles without atretic signs (apoptotic/pycnotic nucleus and loss of cell adhesion in granulosa) were evaluated. Image analysis was performed using Image Pro-Plus 3.0.1 system (Media Cybernetics, Silver Spring, MA, USA). Images were digitized at 40 magnification using an Olympus C5060 digital camera mounted on a conventional light microscope (Olympus BH-2; Olympus Co., Tokyo, Japan). Details of image analysis have been described earlier (Shan et al. 1997, Wang et al. 1999, 2000, Zhu et al. 2000, Salvetti et al. 2007). The nuclei were visualized and identified using AutoPro macro language, an automated sequence operation created to measure the optical density (OD). The images of immunostained slides were converted to an 8 bit gray scale, with the background staining of the histological slides set at zero and the most intense staining set at two. This calibration was carried out using specific tools of the software that determine, through a histogram analysis of the images, the intensity values corresponding to background (represented mainly by cytoplasmic and antral staining) and the most intense staining (in nucleus) independently for each receptor and considering the respective positive and negative controls in each assay. These values were verified and normalized with the controls carried across various runs and the same region (verified by image comparison) was used for calibration. The OD was measured as a mean gray intensity of each pixel divided by the total number of pixels measured. The OD was calculated separately for each follicular compartment (oocyte, granulosa, theca interna, and theca externa) and stroma.

For primordial, primary, and small preantral follicles, all granulosa cells within each follicle were analyzed. For large preantral and antral follicles, 100 cells/compartment/follicle were quantified. To avoid subjectivity and differences in location of cells relative to antrum and theca, vertical rows of all cells spanning between the theca and antrum were quantified until 100 cells were counted (Fig. 1). For each ovary, 200 stromal cells were analyzed, in the centre of the ovary. Sections were analyzed with the observer blinded to treatment.

The major strength of the imaging approach used in this study is visualization of in situ localization of proteins within cells of interest. In the past decade, computerized image analysis systems have been developed to obtain objective and accurate quantification of nuclear markers (Lejeune et al. 2008). This approach has been successfully applied by other investigators to quantify steroid receptors in different tissues and validated for diagnostic, prognostic, and therapeutic purposes (Shan et al. 1997, Wang et al. 1999, 2000, Zhu et al. 2000, Salvetti et al. 2007, Lejeune et al. 2008). Since the immunostaining and image analyses are optimized for each protein, quantitative comparisons across proteins are not possible.

\section{Statistical analyses}

The OD of all cells within each follicular compartment (granulosa, theca, and oocyte) within a follicle class was first averaged and then a group mean across follicles was derived for each follicle type within an animal. When more than one fetus was studied per dam, the data were averaged before analyses. For 21-month-old females, because comparison of data from cycling and anovulatory prenatal T-treated animals revealed no differences in steroid receptor expression, data from cycling and anovulatory animals were treated as one group for analysis. A statistical software package (SPSS 11.0 for Windows; SPSS Inc., Chicago, IL, USA) was used for performing the statistical tests. When more than two groups were involved (control, T-treated, DHT-treated; all ages except 21 months), data were compared by analyses of variance, followed by Duncan's multiple range tests. For comparing results between two groups (control versus T-treated, 21 months), Student's $t$-test was utilized. A $P<0.05$ value was considered significant. Results are expressed as mean \pm s.E.M.

\section{Declaration of interest}

The authors declare that there is no conflict of interest that would prejudice the impartiality of this scientific work. 


\section{Funding}

This study was supported by USPHS grants P01-HD44232 to V P.

\section{Acknowledgements}

We are grateful to Mr Douglas Doop for his expert animal care, facility management, and help with generation of the experimental lambs; Drs Mohan Manikkam, Almudena Veiga-Lopez, Teresa Steckler, Mr James Lee, Ms Carol Herkimer and Ms Olga Astapova for assistance with prenatal steroid treatment, and/or collection, processing, and sectioning of ovaries; and Dr Keith Inskeep for editorial help. We also thank the staff members of the Laboratory of Cellular Biology (FCV$U N L)$ for their technical support during processing of the slides.

\section{References}

Abbott DH, Dumesic DA, Levine JE, Dunaif A \& Padmanabhan V 2006 Animal models and fetal programming of PCOS. In Contemporary Endocrinology: Androgen Excess Disorders in Women: Polycystic Ovary Syndrome and Other Disorders, 2 edn, pp 259-272. Eds R Azziz, JE Nestler \& D Dewailly. Totowa, NJ: Humana Press Inc.

Bahrke MS, Yesalis CE \& Brower KJ 1998 Anabolic-androgenic steroid abuse and performance-enhancing drugs among adolescents. Child and Adolescent Psychiatric Clinics of North America 7 821-838.

Barbieri RL, Saltzman DH, Torday JS, Randall RW, Frigoletto FD \& Ryan KJ 1986 Elevated concentrations of the beta-subunit of human chorionic gonadotropin and testosterone in amniotic fluid of gestations of diabetic mothers. American Journal of Obstetrics and Gynecology 154 1039-1043.

Beato M \& Klug J 2002 Steroid hormone receptors: an update. Human Reproduction Update 6 225-236.

Beck-Peccoz P, Padmanabhan V, Baggiani AM, Cortelazzi D, Buscaglia M, Medri G, Marconi AM \& Pardi G 1991 Maturation of hypothalamicpituitary-gonadal function in normal human fetuses: circulating levels of gonadotropins, their common alpha-subunit and free testosterone, and discrepancy between immunological and biological activities of circulating follicle-stimulating hormone. Journal of Clinical Endocrinology and Metabolism 73 525-532.

Bhavnani BR, Tam SP \& Lu XF 2008 Structure activity relationships and differential interactions and functional activity of various equine estrogens mediated via estrogen receptors $\mathrm{ER} \alpha$ and ER $\beta$. Endocrinology 149 4857-4870.

Billig H, Furuta I \& Hsueh AJW 1993 Estrogens inhibit and androgens enhance ovarian granulosa cell apoptosis. Endocrinology 133 2204-2212.

Britt KL \& Findlay JK 2002 Estrogen actions in the ovary revisited. Journal of Endocrinology 175 269-276.

Bukovsky A, Ayala ME, Dominguez R, Keenan JA, Wimalasena J, Elder RF \& Caudle MR 2002 Changes of ovarian interstitial cell hormone receptors and behavior of resident mesenchymal cells in developing and adult rats with steroid-induced sterility. Steroids 67 277-289.

Catteau-Jonard S, Jamin SP, Leclerc A, Gonzales J, Dewailly D \& di Clemente N 2008 Anti-mullerian hormone, its receptor, FSH receptor, and androgen receptor genes are overexpressed by granulosa cells from stimulated follicles in women with polycystic ovary syndrome. Journal of Clinical Endocrinology and Metabolism 93 4456-4461.

Chadha S, Pache TD, Huikeshoven JM, Brinkmann AO \& van der Kwast TH 1994 Androgen receptor expression in human ovarian and uterine tissue of long-term androgen-treated transsexual women. Human Pathology 25 1198-1204.

Chan L \& O'Malley BW 1976 Mechanism of action of the sex steroid hormones (first of three parts). New England Journal of Medicine 294 $1322-1328$.
Cheng G, Weihua Z, Makinen S, Makela S, Saji S, Warner M, Gustafsson JA \& Hovatta O $2002 \mathrm{~A}$ role for the androgen receptor in follicular atresia of estrogen receptor beta knockout mouse ovary. Biology of Reproduction 66 77-84.

Crain DA, Janssen SJ, Edwards TM, Heindel J, Ho SM, Hunt P, Iguchi T, Juul A, McLachlan JA, Schwartz J et al. 2008 Female reproductive disorders: the roles of endocrine-disrupting compounds and developmental timing. Fertility and Sterility 90 911-940.

Crews D \& McLachlan JA 2006 Epigenetics, evolution, endocrine disruption, health, and disease. Endocrinology 147 S4-S10.

Driscoll SG, Benirschke K \& Curtis GW 1960 Neonatal deaths among infants of diabetic mothers. Postmortem findings in ninety-five infants. American Journal of Diseases of Children 100 818-835.

Drummond AE 2006 The role of steroids in follicular growth. Reproductive Biology and Endocrinology 416.

Drummond AE, Baillie AJ \& Findlay JK 1999 Ovarian estrogen receptor alpha and beta mRNA expression: impact of development and estrogen. Molecular and Cellular Endocrinology 149 153-161.

Drummond AE, Britt KL, Dyson M, Jones ME, Kerr JB, O'Donnell L, Simpson ER \& Findlay JK 2002 Ovarian steroid receptors and their role in ovarian function. Molecular and Cellular Endocrinology 191 $27-33$

Dumesic DA, Abbott DH \& Padmanabhan V 2007 Polycystic ovary syndrome and its developmental origins. Reviews in Endocrine and Metabolic Disorders 8 127-141.

Dunaif A 1997 Insulin resistance and the polycystic ovary syndrome: mechanism and implications for pathogenesis. Endocrine Reviews $\mathbf{1 8}$ 774-800.

Dupont S, Krust A, Gansmuller A, Dierich A, Chambon P \& Mark M 2000 Effect of single and compound knockouts of estrogen receptors a (ER $\alpha$ ) and $\mathrm{b}(\mathrm{ER} \beta)$ on mouse reproductive phenotypes. Development 127 4277-4291.

Franks S, McCarthy MI \& Hardy K 2006 Development of polycystic ovary syndrome: involvement of genetic and environmental factors. International Journal of Andrology 29 278-285.

Gaspar ML, Meo T, Bourgarel P, Guenet JL \& Tosi M 1991 A single base deletion in the $\mathrm{Tfm}$ androgen receptor gene creates a short-lived messenger RNA that directs internal translation initiation. PNAS $\mathbf{8 8}$ 8606-8610.

Gougelet A, Mueller SD, Korach KS \& Renoir JM 2007 Oestrogen receptors pathways to oestrogen responsive elements: transcriptional function-1 acts as the keystone of oestrogen receptor (ER) beta-mediated transcriptional repression of ERalpha. Journal of Steroid Biochemistry and Molecular Biology 104 110-122.

Hall JM \& McDonnell DP 1999 The estrogen receptor $\beta$-isoform (ER $\beta$ ) of the human estrogen receptor modulates ER $\alpha$ transcriptional activity and is a key regulator of the cellular response to estrogens and antiestrogens. Endocrinology 140 5566-5578.

Handa RJ, Pak TR, Kudwa AE, Lund TD \& Hinds L 2008 An alternate pathway for androgen regulation of brain function: activation of estrogen receptor beta by the metabolite of dihydrotestosterone, 5alpha-androstane-3beta,17beta-diol. Hormones and Behavior $\mathbf{5 3}$ 741-752.

Hillier SG \& Tetsuka M 1997 Role of androgens in follicle maturation and atresia. Baillière's Clinical Obstetrics and Gynaecology 11 249-260.

Jellesen R, Strandberg-Larsen K, Jørgensen T, Olsen J, Thulstrup AM \& Andersen AM 2008 Maternal use of oral contraceptives and risk of fetal death. Paediatric and Perinatal Epidemiology 22 334-340.

Juengel JL, Heath DA, Quirke LD \& McNatty KP 2006 Oestrogen receptor alpha and beta, androgen receptor and progesterone receptor mRNA and protein localisation within the developing ovary and in small growing follicles of sheep. Reproduction 131 81-92.

Leader JE, Wang C, Fu M \& Pestell RG 2006a Epigenetic regulation of nuclear steroid receptors. Biochemical Pharmacology 72 1589-1596.

Leader JE, Wang C, Popov VM, Fu M \& Pestell RG 2006b Epigenetics and the estrogen receptor. Annals of the New York Academy of Sciences 1089 73-87.

Lejeune M, Jaén J, Pons L, López C, Salvadó MT, Bosch R, García M, Escrivà $\mathbf{P}$, Baucells J, Cugat $\mathbf{X}$ et al. 2008 Quantification of diverse 
subcellular immunohistochemical markers with clinicobiological relevancies: validation of a new computer-assisted image analysis procedure. Journal of Anatomy 212 868-878.

De Leo V, Lanzetta D, D'Antona D, Marca A \& Morgante G 1998 Hormonal effects of flutamide in young women with polycystic ovary syndrome. Journal of Clinical Endocrinology and Metabolism 83 99-102.

Lydon JP, DeMayo FJ, Funk CR, Mani SK, Hughes AR, Montgomery CA Jr, Shyamala G, Conneely OM \& OMalley BW 1995 Mice lacking progesterone receptor exhibit pleiotropic reproductive abnormalities. Genes and Development 9 2266-2278.

Manikkam M, Crespi EJ, Doop DD, Herkimer C, Lee JS, Yu S, Brown MB, Foster DL \& Padmanabhan V 2004 Fetal programming: prenatal testosterone excess leads to fetal growth retardation and postnatal catch-up growth in sheep. Endocrinology 145 790-798.

Manikkam M, Steckler TL, Welch KB, Inskeep EK \& Padmanabhan V 2006 Fetal programming: prenatal testosterone treatment leads to follicular persistence/luteal defects; partial restoration of ovarian function by cyclic progesterone treatment. Endocrinology 147 1997-2007.

McGee EA \& Hsueh AJ 2000 Initial and cyclic recruitment of ovarian follicles. Endocrine Reviews 21 200-214.

McInerney EM, Weis KE, Sun J, Mosselman S \& Katzenellenbogen BS 1998 Transcription activation by the human estrogen receptor subtype $\beta$ (ER $\beta$ ) studied with ER $\beta$ and ER $\alpha$ receptor chimeras. Endocrinology 139 4513-4522.

McNatty KP, Heath DA, Lundy T, Fidler AE, Quirke L, O'Connell A, Smith P, Groome N \& Tisdall DJ 1999 Control of early ovarian follicular development. Journal of Reproduction and Fertility 54 3-16.

Padmanabhan V, Manikkam M, Recabarren S \& Foster D 2006 Prenatal testosterone excess programs reproductive and metabolic dysfunction in the female. Molecular and Cellular Endocrinology 246 165-174.

Padmanabhan V, Veiga_Lopez, Abbott DH \& Dumesic DA 2007 Developmental programming of ovarian disruption. In Novel Concepts in Ovarian Endocrinology, pp 329-352. Ed. A Gonzalez-Bulnes. India: Research Signpost.

Padmanabhan V, Siefert K, Ransom S, Johnson T, Pinkerton J, Anderson L, Tao L \& Kannan K 2008 Maternal bisphenol-A levels at delivery: a looming problem? Journal of Perinatology 28 258-263.

Palter SF, Tavares AB, Hourvitz A, Veldhuis JD \& Adashi EY 2001 Are estrogens of import to primate/human ovarian folliculogenesis? Endocrine Reviews 22 389-424.

Pettersson K, Grandien K, Kuiper GG \& Gustafsson JA 1997 Mouse estrogen receptor $\beta$ forms estrogen response element-binding heterodimers with estrogen receptor $\alpha$. Molecular Endocrinology 11 1486-1496.

Pettersson K, Delaunay F \& Gustafsson JA 2000 Estrogen receptor beta acts as a dominant regulator of estrogen signaling. Oncogene 19 4970-4978.

Robinson JE, Birch RA, Foster DL \& Padmanabhan V 2002 Prenatal exposure of the ovine fetus to androgens sexually differentiates the steroid feedback mechanisms that control gonadotropin releasing hormone secretion and disrupts ovarian cycles. Archives of Sexual Behavior 31 35-41.

Rosenfeld CS, Roberts RM \& Lubahn DB 2001 Estrogen receptor- and aromatase-deficient mice provide insight into the roles of estrogen within the ovary and uterus. Molecular Reproduction and Development $\mathbf{5 9}$ 336-346.

Rosenfield RL 1997 Is polycystic ovary syndrome a neuroendocrine or an ovarian disorder? Clinical Endocrinology 47 423-424.

Salvetti NR, Acosta JC, Gimeno EJ, Müller LA, Mazzini RA, Taboada AF \& Ortega HH 2007 Estrogen receptors alpha and beta and progesterone receptors in normal bovine ovarian follicles and cystic ovarian disease. Veterinary Pathology 44 373-378.

Salvetti NR, Baravalle C, Mira GA, Gimeno EJ, Dallard BE, Rey F \& Ortega HH 2009 Heat shock protein 70 and sex steroid receptors in the follicular structures of induced ovarian cysts. Reproduction in Domestic Animals [in press].

Schonfelder G, Wittfoht W, Hopp H, Talsness CE, Paul M \& Chahoud I 2002 Parent bisphenol A accumulation in the human maternal-fetalplacental unit. Environmental Health Perspectives 110 A703-A707.
Shan LX, Bardin CW \& Hardy MP 1997 Immunohistochemical analysis of androgen effects on androgen receptor expression in developing Leydig and Sertoli cells. Endocrinology 138 1259-1266.

Shiina H, Matsumoto T, Sato T, Igarashi K, Miyamoto J, Takemasa S, Sakari M, Takada I, Nakamura T, Metzger D et al. 2006 Premature ovarian failure in androgen receptor deficient mice. PNAS 103 224-229.

Simpson ER, Misso M, Hewitt KN, Hill RA, Boon WC, Jones ME, Kovacic A, Zhou J \& Clyne CD 2005 Estrogen: the good, the bad, and the unexpected. Endocrine Reviews 26 322-330.

Smith P, Steckler T, Veiga-Lopez A \& Padmanabhan V 2009 Developmental programming: differential effects of prenatal testosterone and dihydrotestosterone on follicular recruitment, depletion of follicular reserve, and ovarian morphology. Biology of Reproduction 80 726-736.

Steckler T, Wang J, Bartol FF, Roy SK \& Padmanabhan V 2005 Fetal programming: prenatal testosterone treatment causes intrauterine growth retardation, reduces ovarian reserve and increases ovarian follicular recruitment. Endocrinology 146 3185-3193.

Steckler T, Manikkam M, Inskeep EK \& Padmanabhan V 2007 Developmental programming: follicular persistence in prenatal testosteronetreated sheep is not programmed by androgenic actions of testosterone. Endocrinology 148 3532-3540.

Sun J, Meyers MJ, Fink BE, Rajendran R, Katzenellenbogen JA \& Katzenellenbogen BS 1999 Novel ligands that function as selective estrogens or antiestrogen for estrogen receptor- $\alpha$ or estrogen receptor- $\beta$. Endocrinology 140 800-804.

Tang WY, Newbold R, Mardilovich K, Jefferson W, Cheng RY, Medvedovic M \& Ho SM 2008 Persistent hypomethylation in the promoter of nucleosomal binding protein 1 (Nsbp1) correlates with overexpression of Nsbp1 in mouse uteri neonatally exposed to diethylstilbestrol or genistein. Endocrinology 149 5922-5931.

Tenbaum S \& Baniahmad A 1997 Nuclear receptors: structure, function and involvement in disease. International Journal of Biochemistry and Cellular Biology 29 1325-1341.

Tetsuka M \& Hillier SG 1996 Androgen receptor gene expression in rat granulosa cells: the role of follicle-stimulating hormone and steroid hormones. Endocrinology 137 4392-4397.

Tomic D, Frech MS, Babus JK, Symonds D, Furth PA, Koos RD \& Flaws JA 2007 Effects of ER alpha overexpression on female reproduction in mice. Reproductive Toxicology 23 317-325.

Vendola KA, Zhou J, Adesanya OO, Weil SJ \& Bondy CA 1998 Androgens stimulate early stages of follicular growth in the primate ovary. Journal of Clinical Investigation 101 2622-2629.

Vottero A, Capelletti M, Giuliodori S, Viani I, Ziveri M, Neri TM, Bernasconi S \& Ghizzoni L 2006 Decreased androgen receptor gene methylation in premature pubarche: a novel pathogenetic mechanism? Journal of Clinical Endocrinology and Metabolism 91 968-972.

Walters KA, Allan CM \& Handelsman DJ 2008 Androgen actions and the ovary. Biology of Reproduction 78 380-389.

Wang H, Masironi B, Eriksson H \& Sahlin L 1999 A comparative study of estrogen receptors $\alpha$ and $\beta$ in the rat uterus. Biology of Reproduction $\mathbf{6 1}$ 955-964.

Wang $\mathbf{H}$, Eriksson $\mathbf{H}$ \& Sahlin L 2000 Estrogen receptors $\alpha$ and $\beta$ in the female reproductive tract of the rat during the estrous cycle. Biology of Reproduction 63 1331-1340.

West C, Foster DL, Evans NP, Robinson J \& Padmanabhan V 2001 Intra follicular activin availability is altered in prenatally-androgenized lambs. Molecular and Cellular Endocrinology 185 51-59.

Wood RI \& Foster DL 1998 Sexual differentiation of reproductive neuroendocrine function. Reviews of Reproduction 3 130-140.

Wood RI, Ebling FJ, I'Anson H, Bucholtz DC, Yellon SM \& Foster DL 1991 Prenatal androgens time neuroendocrine sexual maturation. Endocrinology 128 2457-2468.

Woodruff TK \& Walker CL 2008 Fetal and early postnatal environmental exposures and reproductive health effects in the female. Fertility and Sterility 89 e47-e51.

Xue Q, Lin Z, Cheng YH, Huang CC, Marsh E, Yin P, Milad MP, Confino E, Reierstad S, Innes J et al. 2007 Promoter methylation regulates estrogen receptor 2 in human endometrium and endometriosis. Biology of Reproduction 77 681-687. 
Yang MY \& Fortune JE 2006 Testosterone stimulates the primary to secondary follicle transition in bovine follicles in vitro. Biology of Reproduction 75 924-932.

Yeh S, Tsai MY, Xu Q, Mu XM, Lardy H, Huang KE, Lin H, Yeh SD, Altuwaijri S, Zhou X et al. 2002 Generation and characterization of androgen receptor knockout (ARKO) mice: an in vivo model for the study of androgen functions in selective tissues. PNAS 99 13498-134503.

Young CY, Johnson MP, Prescott JL \& Tindall DJ 1989 The androgen receptor of the testicular-feminized (Tfm) mutant mouse is smaller than the wild-type receptor. Endocrinology 124 771-775.
Zhu LJ, Hardy MP, Inigo IV, Huhtaniemi I, Bardin CW \& Moo-Young AJ 2000 Effects of androgen on androgen receptor expression in rat testicular and epididymal cells: a quantitative immunohistochemical study. Biology of Reproduction 63 368-376.

Received 24 November 2008

First decision 16 January 2009

Accepted 3 March 2009 